\title{
Reconsidering Transcendence/Immanence. Modernity's Modes of Narration in Nineteenth-Century Arabic Literary Tradition
}

\section{Introduction}

The classical approach to the question of modernity in the Arab world traces its moments and sources of inception (Abu Lughod 1963; Khoury 1983; Yared 2002). This reflects an understanding of modernity in terms of political thought as an option to 'tradition.' In this view, Arab modernity ${ }^{1}$ is usually generated only by a process of adoption from the West. In contrast Charles Taylor, tackling anew the question of modernity in his A Secular Age, carries forward an interpretation of history that is based on the conviction that modernity is more than a set of political beliefs that can be adopted.

Taylor, however, does not try to define modernity in A Secular Age. I read his long narrative as an argument that modernity is our condition of life, which we can only approach by means of storytelling. The main storyline of modernity according to A Secular Age encloses a major historical shift from an understanding in which the world is intertwined with transcendence to an understanding in which the world is conceived of largely as self-contained in its immanence. This major shift within the transcendence/immanence dichotomy is reflected in "modes of narration," as Taylor (2004: 175) has elaborated in an earlier attempt to characterize Western modernity. As examples of the "modes" that Westerners use to make sense of their modernity, he mentions "revolution," "progress," and "nation” (2004: 177).

\footnotetext{
I am very grateful to Florian Zemmin for his critical and thorough reading of this chapter, his valuable advice, and for sharing a few references with me. I also wish to thank Reinhard Schulze, Adrien Zakar, and Feriel Bouhafa for several corrections and suggestions.

1 Recent scholarship on the Arabic literary tradition uses this expression and thus counters the traditional understanding of modernity as a purely Western import (e.g. Sheehi 2004; El-Ariss 2013). One of the first comprehensive attempts to challenge euro-centric historiography of the Arab world was Gran's Islamic Roots of Capitalism (1979).
} 
Grasping modernity as reflected in storytelling, I suggest, is a valid attempt to approach the issue of Arab modernity, for this helps us understand modes of narration in accordance with and in difference to Western modernity. Hence, I argue that during the nineteenth century the Arabic literary tradition also developed new modes of narration. These are found in attempts to imagine the course of history as ruled by the universal principles of progress (taqaddum) and civilization (tamaddun). With stories of human progress Arab thinkers did not necessarily overturn transcendence, but they reconsidered its impact on human society. This also included a pragmatic function: by promoting progress and tamaddun and conceiving of them historically, Arab thinkers were able to share and compare their history with Western history. Thereby the history of Western civilization became part of their new story about the world.

The two examples of this new story I shall tackle in this chapter are neither works of social theory nor historiographical projects. As short narrative digressions these examples form part of the prominent literary works of the nineteenth century reform movement called nahda, the "Arab Renaissance." The first is from the Egyptian Rifa'a al-Tahtawi's account of Paris from 1834, Talkhis alIbriz fi Takhlis Bariz (The Extraction of Pure Gold in the Abridgement of Paris, Takhlis). My second example is drawn from a utopian allegoric novel from 1865 by the Syrian author Fransis Marrash, Ghabat al-Haqq (The Forest of Truth). Although neither of the accounts forms part of a larger historiographical project, as stories about progress and tamaddun, both express new modes of narration that had an impact on such larger historiographical projects.

To apply Taylor's transcendence/immanence dichotomy to the Arabic literary tradition poses a challenge that has to do with the nature of Taylor's own story in A Secular Age as being another story about Western modernity. I shall first discuss this problem and thereby elaborate on how Taylor's basic assumption can be productively applied. I then dedicate my main focus to the aforementioned examples that encompass new modes of narration. Part of these new modes is also a certain image of historical circularity in which the West is granted a decisive role. I will conclude this chapter with a summary of modes of narration of Arab modernity and a remark on conceiving of the secular age in the Arab world.

\section{Transcendence/immanence}

The problem of A Secular Age's normative implications as a risk of excluding other stories from the secular age has been distinctly addressed in this volume as well as elsewhere (Mahmood 2010). Therefore, in the following I limit myself 
to the challenge of applying concepts in Taylor's work to traditions, including the Arabic literary tradition, that are not included in A Secular Age.

The most obvious problem one needs to address has to do with the nature of Taylor's approach, which he bases explicitly on his Christian worldview. Taylor cannot be reproached for this at all, since his aim was to regenerate a self-reflection about the West's anchorage in traditions emerging from "Latin Christendom” (ASA: 21). If we depart from this perspective, a big part of A Secular Age provides a specific hermeneutical means with which to understand a major transformation in the social order in Western Europe. Taylor describes this shift by means of the transcendence/immanence dichotomy, which he deems "tailor-made for our culture" (ASA: 16). Although this dichotomy serves as an interpretative pattern in a Western Christian context, its application to the Arab context seems possible and worthwhile to me. Hence, I want to support this point with two detailed remarks - each of a distinct nature. The first refers to a hermeneutical dilemma, the second is a historiographical argument.

First, drawing the transcendence/immanence dichotomy from the intellectual tradition of Latin Christendom, Taylor tries to grasp the emergence of modernity, or more specifically the secular age. Although Taylor (2010a: 412), when reacting to his reviewers, does not consider this dichotomy "watertight" for all ages, he deems it indispensable to understand "our dominant social imaginary," in other words the social world in which we live. ${ }^{2}$ He thus still assumes a certain constancy of this dichotomy, and it is not a clear-cut historical fact. Rather it is to be seen as a priori, allowing for his specific perspective on modernity as being “our age." This perspective cannot only be explained by Taylor's personal beliefs or his particular choice of sources. ${ }^{3}$ A Secular Age reveals anew the very problem of how to approach modernity from the viewpoint of modernity, or how to approach it in difference to something else that comes to the fore when dealing with the evolution of distinctly modern concepts like "nation," "progress," and "revolution." By approaching modernity with the transcendence/immanence dichotomy as embedded in shorter stories (biographies) as well as "master-narratives of secularization" (Taylor 2010b: 300), Taylor's perspective suggests a way out of this hermeneutical dilemma.

Taylor's story about transcendence/immanence is thus only one particular perspective on modernity. Instead of reading this relation as a theological claim, in this chapter I suggest reading it as a hypothetical premise for my spe-

2 Here Taylor responds to comments of Hauerwas and Coles (2010).

3 Sheehan (2010) argues that Taylor's work is not history in a stricter sense that is directed by empirical evidences. Rather Taylor lays out a theological argument within a historical framework as known from Christian apologetic literature. 
cific purpose. Thus, in this chapter I understand it as a first distinction in order to put into context Arab thinkers' (his)stories, which they brought forward to make sense of their world. Hence, reading Arab modernity as a reconfiguration of storytelling around this basic distinction also helps reconsider the secular age in terms of a global secular age.

Putting into question A Secular Age's historiographical restriction, this last aspect leads to my second argument. According to Saba Mahmood's critique of $A$ Secular Age (2010), scholarship on Arab modernity needs to consider the historical proximity of the Western to the non-Western world. Intellectual similarities to Western modern thought are not surprising for the thinkers I deal with: Fransis Marrash from the Syrian city of Aleppo is known to have originated from a wealthy Arab, mainly melkite Catholic bourgeoisie that had established contacts with Western merchants, missionaries, and scholars from at least the eighteenth century onwards (Wielandt 1992: 119-123; Masters 2001: 98 -118; Patel 2013: 38 58). Marrash also makes many references to the Catholic thought that was certainly part of his education in his hometown before he travelled to Paris in 1867 (Wielandt 1992: 128, 141; Hulw 2006: 56-58). ${ }^{4}$

Along with the engagement with the Catholic Church we need to account for the complexity of the Ottoman context. Most Arabs, that is speakers of Arabic, were subject to the Ottoman Empire. ${ }^{5}$ Rifa'a al-Tahtawi can be seen as an intellectual product of an Ottoman administration that experienced conflict and exchange with European powers for centuries, and from the eighteenth century on followed closely Western political and social developments (Altman 1976; Quataert 2005: 75-86; Aydin 2013: 16-18). The history of global Christianity most prominently represented by Catholicism and the entanglement with European history are only two of many examples for my argument that considering the transcendence/immanence dichotomy in different, but very close contexts, proves plausible.

The examples also indicate that we cannot conceive of a similarity between traditions only by referring to comparable theological presumptions. Moreover, exchange between different traditions is also anchored in Arab history itself. This exchange became most visible in a discourse that was shared by Muslim intellectuals like Tahtawi and Christian thinkers like Marrash during the nineteenth century. With scholarship usually considering the period of Marrash and Tahtawi as having "Arabic visions of modernity" (Freitag 2008), Arabs "con-

4 For an extensive account on catholic missions to the Near East and their impact cf. Heyberger (1994).

5 Revisionism in historiography of the early Ottoman period accentuates continuities, thus relativizing the rupture of 1800 (1798). Cf. Sajdi (2007). 
frontation with modernity" (El-Ariss 2013: 51), "Modern Arab identity" (Sheehi 2004), or simply 'Arab modernity,' it seems appropriate to resume the discussion at this point.

\section{Contours of a new mode of narration}

Nineteenth century Arab thinkers such as Tahtawi and Marrash are often considered part of a movement generally called the nahda. Nahḍ, usually translated as “Arab awakening” or “Arab renaissance” (Tomiche 1993; Patel 2013: 13), denotes a movement that aimed to reform Arab societies beginning in the early nineteenth century. It is often applied to the intellectual discourse that began somewhere between Napoléon Bonaparte's Egyptian campaign (1798-1801) and the process of Ottoman State Reform, or the tanzimat (1839-1876) (Brugman 1984: 8-13; Cachia and Badawi 1992; Charif 2000: 35-86). ${ }^{6}$

Scholarship often links the nahda to its so-called "pioneers" (Sheehi 2004: 13, 196), who were the leading figures of reform in the flourishing cities of the old Ottoman world such as Aleppo, Beirut, Cairo, and Tunis, among others. One of the most famous of these pioneers, Rifa'a Rafi' al-Tahtawi, was a protagonist in the Egyptian educational reform beginning in the early nineteenth century. Egypt's modernization was fostered intensively by the new Khedive's dynasty, which goverened independently from Istanbul and which aimed mainly at reforming education, as well as the economy, the military, and medical institutions in Egypt. Part of this process was the dispatch of missions of promising students to European countries such as Italy and France. Tahtawi was one of these and was sent to Paris in 1826 to acquire new knowledge in natural and technological sciences. After his return to Cairo, he published a travelogue on his experiences in 1834, The Extraction of Pure Gold in the Abridgment of Paris (Takhlis, Newman 2004: 85). Takhlis quickly gained popularity and was translated into Ottoman Turkish as early as $1839 .^{7}$ Nowadays, it is renowned as a milestone in the

6 The origins of the nahda can be traced to the production and the exchange of texts in the eighteenth century/early nineteenth century (Patel 2013; Hill 2015). The term nahda, however, was probably not used before the 1870s (Gonzalez-Quijano 2007: 75). For a discussion of the term and its ideological implications also cf. Johnston (2013: 59-60, 123-124).

7 For renditions on Tahtawi's life in the context of ninenteenth century Egyptian reform, cf. Newman (2004: 15-82), Hourani (1983, 67 -83), Delanoue (1982: Tome 2, Première Partie), and Altman (1976). 
Arabic literary tradition and often regarded as a forerunner of modern Arabic literature (Brugman 1984: 18). ${ }^{8}$

Takhlis, known as a travelogue (rihla; Tahtawi 1958: 56), is not a day-to-day travel report. It bears clear-cut features of an ethno-geographic treatise. ${ }^{9}$ Thus, the content of the treatise is hardly centered on the travel adventure of an individual; rather, it is organized as a systematic description of the geography, climate, and city planning of Paris, as well as of Parisians, their manners, and their customs. Furthermore, it evaluates scientific study in France and the revolution of July 1830, with an extensive commentary on the articles of the new constitution. Takhlis borrows many European terms (Sawaie 2000; Jalal 2006; 2008) and introduces new concepts to an Arab audience (Salama-Carr 2007: 222-224), but it also alludes to the richness and diversity of the Arabic literary heritage (Wagner 2000). Important for my purpose is the way in which Tahtawi presents Europe as part of a common world, revealing a certain mode of narration.

Ostensibly, Tahtawi had to justify his mission. After Takhlis's preface, an introduction precedes the actual travel account with the title "First Chapter. Regarding what seemed to me to be the reason behind our departure to this Land of Infidelity and Obstinacy, which lies far away from us and where there are great expenses because of the high cost of living"10 (Tahtawi 2004: 101). Tahtawi (2004: 101) then expounds on the purpose of the voyage:

Originally, man was simple and devoid of adornments; he existed in a purely natural state, and knew only instincts. Then, some people acquired some knowledge that they had not previously had. This was uncovered to them by chance, accident, inspiration, or revelation. The divine law or the intellect judged that this knowledge was useful, and thus it was applied and preserved. For instance, in earliest times some people were completely ignorant of how to cook food by means of fire, since the latter was completely unknown among them. As a result, their diet was restricted to fruit, things ripened in the sun, or raw foodstuffs, as is still the case in some countries today. Then one of them by chance saw a spark coming from a flint as it was hit with a piece of iron or something like that. When he did the same thing, he managed to extract the fire and learned about its properties.

8 It is also often seen as a starting point for the nahda (Salama-Carr 2007: 216; Johnston 2013: $123-124)$.

9 In its organization, it clearly resonates with Georges-Bernard Depping's Aperçu historique sur les mœurs et coutumes des nations (1826) which Tahtawi read in Paris and published in Arabic just before takhlis (Stephan: 2012; Euben 2008: 117; Elger 2003: 27; Najib 1981: $25-26$ ). A reprint of Tahtawi's translation can be found in Jalal's study (2008).

10 This and the following quotations are from Newman's translation of Tahtawi's travelogue (2004). 
Tahtawi thus does not explain Europe but a general principle of world history. He imagines human origins and man's progressive change toward more refined forms of life. By this he legitimizes the way he approaches the subject of his book. Telling this story of human life, how it is, and how it once must have been or still is, he implies that progress is the leading universal principle in the history of societies. Progress (taqaddum), in Tahtawi's view (1958: 60), is a universal principle that is nonetheless not universally happening in the same way and at the same time, as he makes clear with an apposition phrase when discussing the consumption of raw meat: "as is still the case in some countries today" (see above quotation).

Progress does not occur in the same fashion for all humans and at the same time; instead, it is the outcome of different ultimate causes and depends on the natural surroundings. Yet, from a theoretical point of view, it can happen everywhere and is what societies aim at. In the subsequent section, Tahtawi offers the reader a theory of stages - typical of French Enlightenment thought - probably building on Montesquieu, whom Tahtawi read in France (Tahtawi 2004: 292293). Mankind, the Egyptian explains, can be categorized, according to its proximity to or distance from the original condition (al-hāla al-aṣliyya) (Tahtawi 1958: 58), into several categories. "The first category is that of wild savages, the second of the uncivilized barbarians, whereas the third comprises people who are cultured, refined, sedentarized, civilized, and have attained the highest degree of urbanization" (Tahtawi 2004: 102). All human communities or nations of the world, as well as individuals, can be classified in these categories, with France and Egypt in the third. Although Egypt is advanced, it still needs some knowledge to reach greater splendor. This knowledge is represented by some sciences, in which European countries are at least in partial terms more advanced than the “Islamic countries" (al-bilād al-islāmiyya; Tahtawi 1958: 61). Tahtawi (2004: 105110) justifies Egypt's borrowing from Europe by explaining that Europeans once learned from Islamic countries. Therefore, he implicitly systematizes an approach to different geo-cultural and historical entities, the West (here: Europe), and the Orient (here: the Islamic countries), which I will come back to at the end of this chapter.

\section{Features of the progress story}

Understanding this story as containing progress as a new mode of narration, we first of all need to consider in detail what is new about it. For this purpose it seems worthwhile to make some remarks on premodern conceptualizations of history in the Arabic literary tradition. While a comprehensive view is beyond 
the scope of this chapter, I shall restrict myself to a few features that are related to our premise of the transcendence/immanence dichotomy. In premodern Arabic historical writings, God is usually introduced as the founder of the cosmos, who directed the history of human communities. Transcendence, thus, appears as "the engine of history" (Robinson 2003: 129). The dispatch of messengers and prophets is also an aspect of God's interference, and it was mainly these mediators, by their laws and prophecies, that gave society new directions (Robinson 2003: 133). The people that made change thus were people with names, specific persons that had a prescribed task to fulfill and that disposed of a closer relation to transcendence. In contrast, Tahtawi's story of progress contains a conceptualization of history that is different in three core features:

First, The contingency of change and its multifaceted causes:

Presuming that God is transcendent in the Islamic tradition and that revelation is a human experience of this transcendence, Tahtawi (1958: 59) provides different causes for changes in human behavior, "coincidence" (ittifāq) and "chance" (șudfa), or "revelation" (ihy $\bar{a}$ ') and "inspiration" (ilhām). "Revelation" and "inspiration" seem to be necessarily related to some sort of transcendence, whereas "chance" and "coincidence" seem to be mechanisms relying on their own immanent logic. Whereas the latter two seem to be solely related to human life, the former two denote divine interference. This becomes evident in another sentence of this first section of the introduction in which he juxtaposes two options for change: "divine inspiration" (ilhām ilāhì) and "human coincidence" (ittifāq basharī; Tahtawi 1958: 59). In other words, what matters here is change, not its actual cause. The reasons for change can be diverse, but Tahtawi stresses the point that change is a universal principle. In this case, it is an experience that is Egyptian or Arab as well as French or European, but it is foremost a human experience, and it does not need to be generated by transcendence.

Second, the approbation of knowledge:

According to Tahtawi (1958: 59), both the shari' $a$ as the divinely ordained law and human intellect have the ability to approve things as useful knowledge. ${ }^{12}$ Tahtawi continues to give diverse reasons behind sustainably changing human behaviors. Anchored in the Islamic intellectual tradition, he conveys that under certain conditions, human intellect can reach results similar to those of

11 Here, I rely on Johnston's translations (2013a: 206).

12 This distinction of knowledge seems to be the foundation for his division of sciences (Johnston 2013b). 
the revealed law. By combining this Islamic rationalism ${ }^{13}$ with the historical narrative about mankind, Tahtawi is able to delineate a normative view on progress. ${ }^{14}$ This rationalist worldview, thus, is embedded in the conception of history.

\section{Third, the universal human:}

In Tahtawi's account, human beings are presented as creatures without names or characteristics. Thinking man, in his origin as a primitive species, is probably not compatible with the premodern approach to history, in which the human agent appears often as a specific individual, like the prophets or kings who are leaders of the biblical or Islamic community. Society was founded, instructed, and directed by prophets and messengers who receive no mention in Tahtawi's opening narrative; instead, agency is assigned to man in his most simple definition. Thus this story entails the foundation of universal human history. As part of that history, progress serves as a new mode of narration.

With these features in a story of progress, Tahtawi subscribes to a conception of human life as mostly independent from transcendent guidance. Tahtawi imagines human history, takes empirical knowledge and systematizes it in a chronological and causal manner. Thus, 'imagining' is not a placeholder for terms like 'inventing' or 'fictionalizing'. I understand it as that which is thinkable and therefore possible in the view of this author and his implied reader. Tahtawi's story entails a new story about the world.

As a matter of fact, the way Tahtawi thought of societal change here was reflected in his later historiographical project (Tahtawi 2010/2011). He composed a comprehensive history of Egypt of which the first volume (1868) was published before and the second volume just after his death in $1874 .{ }^{15}$ Giving the history of Egypt before the advent of Islam in the first volume of this historiography, Tahtawi begins with the geography of the lands and its dynasties. Then he interestingly frames his second volume as a biography of Muhammad, the prophet of Islam, including accounts of the social organization the prophet established.

Instead of inserting Egypt into the traditional history of the Islamic community, Tahtawi includes patterns of Islamic history in Egypt's national history and

13 On Islamic rationalism, cf. Mahdi (2001) and R. Taylor (2009).

14 Although there were Arabic/Islamic notions of scientific progress in premodern times, as Khalidi (1981) has shown, they did not seem to be part of the discourse of renewal modifying the approach to human history, as is the case in the nineteenth century.

15 On his late publications cf. Newman (2004: 67-68). 
views the latter as an example for the world. More importantly, Tahtawi imagines history according to new principles that can be derived from the aforementioned narrative, depicting immanently organized human society depending on the land where it dwells (pre-Islamic Egypt) ${ }^{16}$ and change understood as human progress that can, but does not have to, be successfully triggered by God's interventions (Islamic Egypt). Ancient Egypt, Tahtawi (2010/2011, 3: 32) explains in his first volume, had already achieved "civilization and progress" (al-tamaddun wa-l-taqaddum). ${ }^{17}$

\section{The concept of tamaddun/civilization}

Tahtawi's story focuses on people's capacity for progress. The aim of the Egyptian mission to France was to bring home something new in order to change state institutions. Based on the paradigm of progress, the need for comprehensive reform in the nineteenth century in different regions in the Arab world developed to form a broader project that was most profoundly expressed by the term tamaddun. This usually translates as “civilization" (Konrad 2011: 175; Zachs 2012; 2005: 67; Schäbler 2004: 23; Sheehi 2004: 12). Tahtawi (1958: 60) had already used the term in 1834 in Takhlis when describing the aforementioned third and most advanced category of human societies. Tamaddun originally denoted the process of becoming a city dweller (Marrash 1881: 57; Bustani 1977: 843), and city life in general must be subsumed - according to Tahtawi under the third category of societies in the world.

Tamaddun became a popular concept in the 1850s, most probably peaking in the decades thereafter, and persisted until the twentieth century. ${ }^{18}$ It acquired a strong quality of enthusiasm in Fransis Marrash's novel Ghabat al-Haqq (1865),

16 After an introduction in which ancient Egyptian society is introduced as containing features of progress, Tahtawi (2010/2011, 3: 41-88) defines the geographical borders of Egypt and depicts its landscape and its nature by focusing on the Nile and its value.

17 This approach to history is outlined by Crabbs (1984: 67-82), drawing mainly on Tahtawi's Manahij al-albab al-misriyya (1869). Already Hourani (1983: 79-81) refers to this book by depicting Tahtawi's conceptualization of ancient Egyptian history.

18 A similar categorization in which tamaddun denotes the most refined group of people can be found in Butrus al-Bustani's Discourse on Society (1999). In trying to understand social life in Beirut in a systematic fashion, Bustani also refers to a stage paradigm similar to that elaborated upon in Tahtawi's Takhlis and draws on Ibn Khaldun's (1332-82 AD) dualism of country life/ city life (Sheehi 2004: 208fn52). The concept of tamaddun in the nineteenth century included in fiction and travel writings is discussed in Wielandt's Das Bild der Europäer (1980: 130-136) and El-Ariss (2013: Chapter 3). 
in which tamaddun is presented as a guiding principle for human well-being. Like Lebanese authors of his time, Marrash probably considered it a means of overcoming sectarian tensions that led to clashes in Aleppo, Damascus, and Mount Lebanon during the 1850s and 1860s (Krimsti 2014; Makdisi 2002; Masters 2001: 156 -165). Marrash was a physician and a poet from a Greek-Catholic bourgeois family in Aleppo, and he travelled to Paris in $1867 .{ }^{19}$ Only at the end of his short life did he shift, as did some other thinkers of his time, from a belief in the universality of progress to a harsh criticism toward European civilization, which in his view revealed a barbarian character (Barut 1994: 81-82; Hulw 2006: 180 193). Before further considering his view on Europe, what is of interest here is the utopian vision that he formulated around the concept of tamaddun in $1865 .^{20}$

Marrash embraces tamaddun in his novel in various respects. First of all and most prominently, it appears as a reform program he bases on five pillars: political education, the cultivation of the intellect, the refinement of social customs and individual morals, the improvement of cities, and love (al-mahabba) as a cosmological unifying power serving social cohesion (Marrash 1881: 57-95). Tamaddun in Marrash's novel most crucially implies thoughts on how contemporary society is best organized. Apart from true moral refinement and scientific progress, tamaddun also covers principles of equality, welfare, and just rulership. The narrator explains all these principles within the dynamics of social organization as a closed and coherent system (Marrash 1881: 58) that clearly has as its background Christian as well as Islamic ideals such as charity and justice of the ruler. However, it is installed only by man's ability to lead a civilized social life.

Similar to progress, tamaddun is more than just a program. Marrash's The Forest of Truth is primarily an allegorical dream narrative (Wielandt 1992: 125). ${ }^{21}$ The narrator directs the reader through a dream world that he himself encounters in a deep sleep. This world consists mainly of a thick forest with a few glades that seem without any geographical attribution. At the center of the narration is a dialogue between the "king of freedom" and the "queen of wisdom" who meet with a wise old "philosopher." After their "kingdom of freedom and civilization" (mamlakat al-hurriyya wa-l-tamaddun; Marrash 1881: 22) has won the war against the barbarous "kingdom of slavery" (mamlakat al-'ubūdiyya; Marrash 1881: 9), their discussion is mainly of the following. How should the prisoners of war be treated? Should they be punished? How should they be in-

19 On Marrash's travelogue cf. Wielandt (1980: 98-104).

20 On Marrash's life in the context of his time cf. Wielandt (1992), Barut (1994), Hulw (2006), Moosa (1997: 186-195), El-Enany (2012: 22 - 24), and Elshakry (2013: 144-145).

21 As Elshakry (2013: 357fn69) suggests Marrash's novel could be read as a play. 
tegrated into the kingdom? The philosopher is the one who has answers to every thorny issue the king and queen need to resolve. He also explains the aforementioned five pillars of tamaddun, adding that they are part of the human condition and "a law which guides man towards the perfection of his natural and moral conditions" (Hourani 1983: 248).

Tamaddun, as becomes clear in the philosopher's monologues, also entails law (shari' $a$ ) and governance (siyāsa). In order to display the human need for law and governance, the philosopher embarks on a historical digression about their origin and with it the origin of the "kingdom of freedom and civilization" (Marrash 1881: 41-54). His story presents mankind throughout its origins. At first it was a community rudimentarily organized socially and located somewhere on a steppe. Accidentally, the leader of this community discovers a promisingly green place on the horizon that turns out to be a forest. He guides his family to it, and in this more fertile environment, he finally builds up his kingdom, which later becomes 'civilized'.

This story line resembles the opening narrative in Tahtawi's travelogue. Human society is presented in its primitive stage and consists of nonspecific human beings. Change then occurs accidentally through man's interaction with his environment, resulting in improvement and eventually mankind's progress and tamaddun. Hence, this "historical inference" (istintāj tarīkhī; Marrash 1881: 40), by building similarly on the origin of mankind and its inclination toward improvement from a perspective of "general history" (tarīk 'āmm; Marrash 1881: 42), indicates a similar mode of narration that is expressed with tamaddun/ civilization.

There are some differences between Marash's and Tahtawi's versions of progress. In the story of The Forest of Truth, God does not interfere in the temporal dynamics of the social order which like all other things seems to be part of his "purposeful design" (Elshakry 2013: 145). ${ }^{22}$ Tamaddun is the cause for change. Thus, Tamaddun is conceived of as an internal stimulus that tautologically leads to its own realization. It is, in other words, the foundational principle of human social organization. ${ }^{23}$ Second, Marrash conveys that this internal stimu-

22 Based on her study of Marrash's later treatise Nature's Testimony (Shahadat al-tabi'a fi wujud Allah wa-al-shari'a), Elshakry (2013: 144-147) describes Marrash's concept of God's relation to the universe as deistic. She suggests reading Marrash's work as a contribution to natural theology. It might be possible that Marrash was exposed to neo-Thomist ideas during his stay in Paris (Elshakry 2013: 146).

23 Hence, tamaddun itself obtains a transcendent character. Sheehi's (2004: 143) observations of nahdha thought confirms this conclusion. 
lus is related to a comprehensive program of reform, similar to Tahtawi's, in which change is an inclination of man that is triggered by natural surroundings.

\section{Conceiving of the West}

Another similarity between Tahtawi's and Marrash's view of progress is related to the belief in exterior impulses. In order to grasp the nineteenth century's new modes of narration, I suggest looking at images of the West as one main impulse. The West, as I argue, forms part of the story about the world and must be considered indispensable for the new modes of narration exemplified by Tahtawi and Marash.

Like Tahtawi who wrote about his journey to France in order to launch into reflections on progress, it is in the end the West that engenders change in The Forest of Truth. Just before the narrator awakens from his dream at the end, he finds himself exiled from the forest and alone on a steppe. Looking westward, he discerns a flood of growing greenery approaching him covering the entire desert and giving him feelings of release and delight. By evoking this image, Marrash (1881: 133-134) clearly alludes to his homeland of Syria and his city of Aleppo and its need to acquire Western innovations. ${ }^{24}$

This finale resonates with the introduction to Marrash's novel (1881: 2). In the introduction, the narrator describes himself falling into a slumber that lets him see the kingdoms of the world rising and falling in front of his eyes, including the old Egyptians, the Assyrians, the Greeks, and the Romans, among others. By referring to a history of societal change and progress, he first asserts that the best movers for successful social systems are reason ('aql) and science ('ilm; Marrash 1881: 3-4). Secondly, beginning with older ancient civilizations and ending this introduction with the Roman Empire, of which as it seems according to his view the modern world was a late outcome, he also alludes to the idea of the natural rise and fall of civilizations. ${ }^{25}$

This latter idea, as well as the importance given to reason and scientific progress, also formed part of the intellectual movement later described as "Is-

24 Similarily, Marrash (2004: 24-26) describes the backwardness of his hometown of Aleppo in his travelogue Rihlat Baris from 1867.

25 Conversely to earlier conceptions of the rise and fall of dynasties/states, as in Ibn Khaldun's theory of history (Khalidi 1981: 283-285), a rise in nahdha discourse was seen as the main ambition in this era (Sheehi 2004: 143). 
lamic reformism" (Kohn 2009). ${ }^{26}$ Adherents to this movement looked to the notions of progress articulated in Islamic scriptures (Ivanyi 2007). Like these reformers, however, Marrash some years after the publication of The Forest of Truth (1865) underlines the fact that Europeans built their civilization originally on knowledge that they once adopted from Arabic civilizations (Hulw 2006: 186). Tahtawi also proposed in Takhlis the idea that Europeans adopted knowledge from Islamic countries. Hence, he legitimized Egypt's adoption of European knowledge, and with it he pronounced the need for "all nations of Islam" to awake from their "slumber" (Tahtawi 1958: 58).

The idea of adopting knowledge, sciences, and technologies seems to justify the "backwardness" of Arabs, which some thinkers began to express in the middle of the nineteenth century (Sheehi 2004: 61-65; 2005: 438-439). The already important role Arabs or Islam played in world history probably fostered the belief that they could regain the scepter of tamaddun. The notions of progress and tamaddun were thus shaped by an idea of circularity, which included the Western world in a common temporality. ${ }^{27}$ The West and the Arab world thus became able to be considered as different historical entities in their own right but functioning according to the same principles.

Circularity may have had a twofold impact on the conception of progress. Progress is not merely thought to be linear; it can decrease, and with this, civilizations can reach their end. Civilizations can thus fall back into "earlier" stages of progress, and in Marrash's understanding, tamaddun can even degrade toward barbarism (tawaḥush; Hulw 2006: 182-183). Thus, progress as a mode of narration did not necessarily lead them to believe in the coming "end of history;" rather, most nahda writers saw themselves and their society as being in one of many circles that improved or lead to a new tamaddun. In the stories of progress (Tahtawi) and tamaddun (Marrash) aspects of circularity and the West's part in it, Arab modernity becomes a complex set of modes of narrations.

\section{Conclusion}

The new modes of narration in the Arabic literary tradition are centered on the normativity and historicity of progress. This we can find expressed in the stories of Arab modernity I have exemplified in this chapter. According to this story,

26 Al-Azmeh (1996: 121-122) observes a continuation between Marrash's understanding of transcendence and later islamic thought.

27 Roussillon (2001: 161) asserts the idea of a universal human temporality for Tahtawi's worldview. 
human society can develop independently from transcendent interference. Arab thinkers both made sense of Western progress and valued advances in the reform process during the Nahda period. Transcendence, however, did not disappear from the stage of history. Arab intellectuals instead reconsidered its role. Transcendent interference in modern Arab conceptualizations of history turned out to be of a particular nature. In addition to the universal principles of tamaddun and progress, transcendent interference, or revelation, becomes a marker for the cultural historical entity Arab thinkers saw themselves belonging to. This was later called the Arab nation or the "Islamic civilization" (al-tamaddun al-islämī). The latter expression, used as the title for a historiographical project in the early twentieth century (Philipp 1979: 90 -93; Dupont 1996; Sheehi 2004: 160 -162; Johnston 2013: 69-71), reveals two themes: a basic and universal understanding of the world consists of civilizations, and a particular designation of one of these civilizations is "Islamic," which alludes to the role of transcendence in history.

Two remarks remain to be made in relation to this last aspect. The option for a history without God has to be put into context. We have to ask on which convictions Tahtawi, Marrash, and others based their conception of an immanent history moved by accident or natural inclinations. In the later nineteenth century, the interaction between European ideas and thinkers in the Arab world certainly played a role, but this cannot be the entire explanation. Examining different ways societies can change must be anchored in the Arabic literary tradition, so that a universal story of mankind, as Tahtawi conceived of it already in 1834 in Takhlis, makes sense to its audience. This requires a deeper look into older Arabic historiographical and philosophical conceptions of time and change and their anchorage in the different traditions of Islam and Christianity. Despite similarities between Western and Arab worldviews in the nineteenth century, one must question whether the intertwinement of transcendence and immanence ever existed in the Arab world to the extent that Taylor assumes it did in Western Europe.

Second, in the historical conceptualization presented here, the West is granted a decisive role in engendering change. The reconsideration of transcendence/ immanence within a new story about the world thus seems to already pave the way for Western modernity as a thinkable option for fostering renewal and reform. In a discussion of the secular age from an Arab perspective one must take into consideration this inclusivist standpoint and the conceptualization of different cultural entities related to it. Thinking modernity in the Arabic context thus entails thinking cultural difference. 


\section{Bibliography}

Abu-Lughod, Ibrahim. 1963. Arab Rediscovery of Europe: a Study in Cultural Encounters. Princeton: Princeton University Press.

Al-Azmeh, Aziz. 1996. Islams and Modernities. New York, London: Verso.

Altman, Israel. 1976. The Political Thought of Rifa'ah Rafi' al-Tahtawi: a Nineteenth Century Egyptian Reformer. Los Angeles: Univ. of California [Diss.].

Ayalon, Ami. 1987. Language and Change in the Arab Middle East: The Evolution of Modern Arab Political Discourse. Oxford: Oxford University Press.

Aydin, Cemil. 2013. The Politics of Anti-Westernism in Asia: Visions of World Order in Pan-Islamic and Pan-Asian Thought. New York: Columbia University Press.

Badawi, Muhammad Mustafa, and Pierre Cachia. 1992. "Introduction," in Modern Arabic Literature, Cambridge History of Arabic Literature, ed. M.M. Badawi, 1-35. Cambridge: Cambridge University Press.

Barut, Muhammad Jamal. 1994. Harakat at-Tanwir al-'Arabiyya fi al-Qarn al-Tasi' 'Ashar. Halqat Halab. Damascus: Manshurat Wizarat al-Thaqafa.

Brugman, Jan. 1984. An Introduction to the History of Modern Arabic Literature in Egypt. Leiden: E.J. Brill.

Bustani, Butrus. 1977. Muhit al-Muhit. Qamus Mutawwal li-l-Lugha al-'Arabiyya. Beirut: Maktabat Lubnan.

Bustani, Butrus. 1999. Khitab fi al-Hay'a al-litima'iyya wa-l-Muqabila bayna al-'Awa'id al-'Arabiyya wa-l-Franjiyya. Kaslik: Jami'at al-Ruh al-Qudus.

Charif, Maher. 2000. Rihanat al-Nahda fi al-Fikr al-'Arabi. Damascus: Dar al-Mada.

Crabbs, Jack A. 1984. The Writing of History in Nineteenth-Century Egypt. Cairo, Detroit: The American University in Cairo Press.

Delanoue, Gilbert. 1982. Moralistes et Politiques Musulmans. Tome I. Le Caire: Institut Français d'Archéologie Orientale du Caire.

Dupont, Anne-Laure. 1996. "L'Histoire de l'Islam au Regard des Autres Histoires. Un Article de Jurji Zaydan Traduit par A. Dupont." Arabica 43, no. 3: 486-493.

El-Ariss, Tarek. 2013. Trials of Arab Modernity: Literary Affects and the New Political. New York: Fordham University Press.

El-Enany, Rasheed. 2012. Arab Representations of the Occident: East-West Encounters in Arabic Fiction. London: Routledge.

Elger, Ralf. 2003. "Arabic Travelogues from the Mashrek 1700-1834. A Preliminary Survey of the Genre's Development," in Crossing and Passages in Genre and Culture, eds. Christian Szyska and Friederike Pannewick, 27-40. Wiesbaden: Reichert.

Elshakry, Marwa. 2013. Reading Darwin in Arabic, 1860-1950. Chicago, London: University of Chicago Press.

Euben, Roxanne L. 2008. Journeys to the Other Shore: Muslim and Western Travelers in Search of Knowledge. Princeton: Princeton University Press.

Freitag, Ulrike. 2008. “Arabische Visionen von Modernität im 19. und frühen 20. Jahrhundert: Die Aneignung von Universalien oder die Übernahme fremder Konzepte?,” in Selbstbilder und Fremdbilder. Repräsentationen sozialer Ordnungen im Wandel, eds. Jörg Baberowski, Hartmut Kaelbe, and Jürgen Schriewer, 89-117. Frankfurt, New York: Campus. 
Gonzalez-Quijano, Yves. 2007. "La Renaissance Arabe au XIXe Siècle: Médiums, Médiations et Médiateurs," in Histoire de la Littérature Arabe Moderne. Tome I (1800-1945), eds. Boutros Hallaq and Heidi Toelle, 71-113. Paris: Sindbad.

Gran, Peter. 1979. Islamic Roots of Capitalism: Egypt, 1760-1840. Austin: University of Texas Press.

Hauerwas, Stanley, and Romand Coles. 2010. "'Long Live the Weeds and the Wilderness Yet': Reflections on A Secular Age.” Modern Theology 26, no. 3: 349-362.

Heyberger, Bernard. 1994. Les Chrétiens du Proche-Orient au Temps de la Réforme Catholique (Syrie, Liban, Palestine, XVIIe-XVIIIe siècles). Rome: Ecole Française de Rome.

Hill, Peter. 2015. "The first Arabic Translations of Enlightenment Literature. The Damietta Circle oft he 1800s and 1810s." Intellectual History Review 25, no. 2: 209-233.

Hourani, Albert Habib. 1983. Arabic Thought in the Liberal Age, 1798-1939. Cambridge: Cambridge University Press.

al-Hulw, Karam. 2006. Al-Fikr al-Libarali 'inda Fransis al-Marrash. Beirut: Markaz Dirasat al-Wahda al-'Arabiyya.

Ivanyi, Katharina. 2007. "God's Custom Concerning the Rise and Fall of Nations: the Tafsir al Manar on Q 8:53 and Q 13:11." The Maghreb Review 32, no. 1: 91-103.

Jalal, Iman al-Sa'id. 2008. Alfaz al-Hadara fi Misr bi al-Qarn al-Tasi' 'Ashar. Cairo: Maktabat al-Adab li-l-Tiba'a wa-l-Nashr wa-l-Tawzi'.

Jalal, Iman al-Sa'id. 2006. al-Mustalah 'inda Rifa'a al-Tahtawi bayna al-Tarjama wa-l-Ta'rib. Cairo: Maktabat al-Adab.

Johnston, Elizabeth E. 2013a. Reading Science in Early Writings of Leopold Zunz and Rifa'a Rafi' al-Tahtawi: On Beginnings of the Wissenschaft des Judentums and the Nahdha. New York: Columbia University [Diss.].

Johnston, Elizabeth E. 2013b. "Classification and Critique of Sciences in al-Tahtawi's Takhlis (1834)." Middle Eastern Literatures 16, no. 3: 282-299.

Khalidi, Tarif. 1981. "The Idea of Progress in Classical Islam." Journal of Near Eastern Studies 40, no. 4: $277-289$.

Khoury, Raif G. 1983. Modern Arab Thought: Channels of the French Revolution to the Arab East. Princeton: Kingston Press.

Kohn, Margaret. 2009. “Afghani on Empire, Islam, and Civilization." Political Theory 37, no. 3: $398-422$.

Konrad, Felix. 2011. “'Fickle Fate Has Exhausted My Burning Heart': An Egyptian Engineer of the 19th Century Between Belief in Progress and Existential Anxiety." Die Welt des Islams 51:145-187.

Krimsti, Feras. 2014. Die Unruhen von 1850 in Aleppo. Gewalt im urbanen Raum. Berlin: Klaus Schwarz.

Mahdi, Muhsin. 2001. "The Rational Tradition in Islam," in Intellectual Traditions in Islam, ed. Farhad Daftary, 43-65. London: I.B. Tauris.

Mahmood, Saba. 2010. "Can Secularism be Otherwise?," in Varieties of Secularism in a Secular Age, eds. Michael Warner, Jonathan Van Antwerpen, and Craig J. Calhoun, 282-299. Cambridge: Harvard University Press.

Makdisi, Ussama. 2002. "After 1860: Debating Religion, Reform, and Nationalism in the Ottoman Empire." International Journal of Middle East Studies 34, no. 4: 601-617.

Marrash, Fransis. 1881. Ghabat al-Haqq. Beirut: Matba'at al-Qiddis Jawurjiyus li-l-Rum al-Urtudhuks. 
Marrash, Fransis. 2004. Kitab Rihlat Baris. Beirut: al-Mu'assasa al-'Arabiyya li-l-Dirasat wa I-Nashr.

Masters, Bruce. 2001. Christians and Jews in the Ottoman Arab World. The Roots of Sectarianism. Cambridge Studies in Islamic Civilization. Cambridge: Cambridge University Press.

Moosa, Matti. 1997. The Origins of Modern Arabic Fiction. Boulder, London: Lynne Rienner Publishers.

Najib, Naji. 1981. al-Rihla ila al-Gharb wa-l-Rihla ila al-Sharq. Dirasa Muqarina. Beirut: Dar al-Kalima.

Newman, Daniel L. 2004. An Imam in Paris: Account of a Stay in France by an Egyptian Cleric (1826-1831). London: Saqi.

Patel, Abdulrazzak. 2013. The Arab Nahdha. The Making of the Intellectual and Humanist Movement. Edinburgh: Edinburgh University Press.

Philipp, Thomas. 1979. Ğurği Zaidān, his Life and Thought. Beirut: Orient-Institut der Deutschen Morgenländischen Gesellschaft.

Quataert, Donald. 2005. The Ottoman Empire, 1700-1922. Cambridge: Cambridge University Press.

Robinson, Chase F. 2003. Islamic Historiography. Cambridge: Cambridge University Press. Roussillon, Alain. 2001. “'Ce qu'ils Nomment 'liberté.': Rifa'a al-Tahtawi, ou l'Invention (Avortée) d'une Modernité Politique Ottomane.” Arabica 48, no. 2: 143-185.

Sajdi, Dana. 2007. "Decline, its Discontents and Ottoman Cultural History: By Way of Introduction," in Ottoman Tulips, Ottoman Coffee: Leisure and Lifestyle in the Eighteenth Century, ed. Dana Sajdi, 1-40. London: IB Tauris \& Company.

Salama-Carr, Myriam. 2007. "Negotiating Conflict: Rifa'a Rafi' al-TahTawi and the Translation of the "Other" in Nineteenth-Century Egypt." Social Semiotics 17, no. 2: 213-227.

Sawaie, Mohammed. 2000. "Rifa'a Rafi' al-Tahtawi and his Contribution to the Lexical Development of Modern Literary Arabic." International Journal of Middle East Studies 32, no. 3: $395-410$.

Schäbler, Birgit. 2004. "Civilizing Others. Global Modernity and the Local

Boundaries (French/German/Ottoman and Arab) of Savagery," in Globalization and the Muslim World. Culture, Religion, and Modernity, ed. Birgit Schäbler and Leif Steinberg, 3-31. New York: Syracuse University Press.

Sheehan, Jonathan. 2010. "When Was Disentchantment? History and the Secular Age," in Varieties of Secularism in a Secular Age, ed. Michael Warner, Jonathan Van Antwerpen, and Craig J. Calhoun, 217-242. Cambridge, Mass.: Harvard University Press.

Sheehi, Stephen. 2004. Foundations of Modern Arab Identity. Gainesville: University Press of Florida.

Sheehi, Stephen. 2005. "Arabic Literary-Scientific Journals: Precedence for Globalization and the Creation of Modernity." Comparative Studies of South Asia, Africa, and the Middle East 25, no. 2: $438-448$.

Stephan, Johannes. 2012. "Wie man die anderen verstehen soll und wie man über sie schreiben kann. Der Paris-Bericht Rifa'a Rafi' at-Tahtawis (1801-1873) als vielseitige Vermittlung von 'Kultur'." zeitenblicke 11, no. 1. http://www.zeitenblicke.de/2012/1/Ste phan/index_html (last accessed October 4, 2013). 
al-Tahtawi, Rif'a Badawi Rafi'. 1958. Takhlis al-Ibriz fi Talkhis Bariz. Ashrafa 'ala Ikhraj hadha al-Kitab wa-Haqqaqahu wa-'Allaqa 'alayhi wa-Qaddama la-hu: Mahdi 'Allam wa-Ahmad Ahmad Badawi wa-Anwar Luqa. Cairo: Wizarat al-Thaqafa wa-l-Irshad al-Qawmi. al-Tahtawi, Rif'a Badawi Rafic. 2004. An Imam in Paris: Account of a Stay in France by an Egyptian Cleric (1826-1831), trans. Daniel L. Newman. London: Saqi.

al-Tahtawi, Rif'a Badawi Rafi'. 2010/2011. al-'Amal al-Kamila. Vol. 3\&4; Tahqiq Muhammad 'Ammara. Cairo: Dar al-Shuruq.

Taylor, Charles. 2004. Modern Social Imaginaries. Durham, London: Duke University Press.

Taylor, Charles. 2010a. "Challenging Issues About the Secular Age." Modern Theology 26, no. 3: $404-416$.

Taylor, Charles. 2010b. "Afterword. Apologia pro Libro Suo," in Varieties of Secularism in a Secular Age, eds. Michael Warner, Jonathan Van Antwerpen, and Craig J. Calhoun, 300-321. Cambridge, Mass.: Harvard University Press.

Taylor, Richard C. 2009. “Ibn Rushd/Averroes and 'Islamic' Rationalism.” Medieval Encounters 15:225-235.

Tomiche, Nadia. 1993. "Nahḍa." Encyclopédie de l'Islam, deuxième édition, tome VII, 901-904.

Wagner, Ewald. 2000. "Die literarische Gestaltung von at-Tahtawis Bericht über seinen Aufenthalt in Paris (1826-1831)," in Beschreibung der Welt: zur Poetik der Reise- und Länderberichte, eds. Xenja von Ertzdorff and Rudolph Schulz, 427-445. Amsterdam, Atlanta: Rodopi.

Wielandt, Rotraud. 1980. Das Bild der Europäer in der modernen arabischen Erzähl- und Theaterliteratur. Wiesbaden: Franz Steiner.

Wielandt, Rotraud. 1992. "Fransîs Fathallâh Marrâshs Zugang zum Gedankengut der Aufklärung und der Französischen Revolution,” in The Middle East and Europe. Encounters and Exchanges, eds. Geert Jan van Gelder and

Ed de Moor, 116-146. Amsterdam, Atlanta: Rodopi.

Yared, Nazik Saba. 2002. Secularism and the Arab World: 1850-1939. London: Saqi Books.

Zachs, Fruma. 2005. The Making of the Syrian Identity: Intellectuals and Merchants in Nineteenth Century Beirut. Leiden: Brill.

Zachs, Fruma. 2012. "Cultural and Conceptual Contributions of Beiruti Merchants to the Nahda." Journal of the Economic and Social History of the Orient 55, no. 1: 153-182. 
